\title{
Detrital zircon (U-Th)/He ages from Paleozoic strata of the Severnaya Zemlya Archipelago: Deciphering multiple episodes of Paleozoic tectonic evolution within the Russian High Arctic
}

\author{
Victoria Ershova $^{\mathrm{a}, *}$, Owen Anfinson ${ }^{\mathrm{b}, \mathrm{c}}$, Andrei Prokopiev ${ }^{\mathrm{d}}$, Andrei Khudoley ${ }^{\mathrm{a}}$, Daniel Stockli ${ }^{\mathrm{b}}$, \\ Jan Inge Faleide ${ }^{\mathrm{e}}$, Carmen Gaina ${ }^{\mathrm{e}}$, Nikolay Malyshev ${ }^{\mathrm{f}}$ \\ a St. Petersburg State University, University nab. 7/9, St. Petersburg, 199034, Russia \\ b Jackson School of Geoscience, University of Texas at Austin, Austin, USA \\ ' Sonoma State University, Rohnert Park, USA \\ d Diamond and Precious Metal Geology Institute Siberian Branch Russian Academy of Sciences, Yakutsk, Russia \\ e Centre for Earth Evolution and Dynamics, Department of Geosciences, University of Oslo, Norway \\ ${ }^{\mathrm{f}}$ Rosneft, Moscow, Russia
}

\section{A R T I C L E I N F O}

\section{Keywords:}

Arctic

Kara sea

Paleozoic paleogeography

Exhumation history

Detrital zircon

Thermochronology

\begin{abstract}
A B S T R A C T
Combined (U-Th)/He and U-Pb detrital zircon geochronological data are reported from Ordovician to Devonian strata of the Severnaya Zemlya archipelago to address the paleogeography of the Kara Terrane in the Russian High Arctic. (U-Th)/He ages from all six samples analyzed were not reset after sediment deposition, indicating that detrital zircons carry information on the exhumation history in the source region of the clastic material. In Ordovician-Silurian strata, (U-Th)/He ages range from $583.8 \pm 46.7$ to $429.0 \pm 34.3 \mathrm{Ma}$. These ages nicely coincide with significant regional exhumation during the Caledonian and Timanian orogenies. In addition, combined $\mathrm{U}-\mathrm{Pb}$ and (U-Th)/He dating show that within the source region, zircons that were crystalized during the Timanian Orogeny (U-Pb ages 680-560 Ma) were likely exhumed during younger Caledonian events ((U$\mathrm{Th}) / \mathrm{He}$ ages of 455-495 Ma), suggesting potential overlap of these orogens within the source region. In Devonian strata, detrital zircon (U-Th)/He ages range from $517.2 \pm 41.38$ to $332.9 \pm 26.6 \mathrm{Ma}$, with a peak age of ca. $375 \mathrm{Ma}$. This $375 \mathrm{Ma}$ event may be correlated with either the Ellesmerian Orogeny or the terminal Solundian/Svalbardian stages of the Caledonian Orogeny.
\end{abstract}

\section{Introduction}

The present day geological structure of the Arctic consists of a collage of terranes of various ages that are either adjacent, or attached, to three large Precambrian cratons: Laurentia, Baltica and Siberia (Fig. 1a). The marginal terranes and cratons are separated by two large, late Mesozoic and Cenozoic oceanic basins, the Amerasian Basin and the Eurasian Basin respectively (Fig. 1a). A number of different Paleozoic and Mesozoic paleogeographic models of the Arctic have been recently published (e.g. Anfinson et al., 2012; Beranek et al., 2013; Brumley et al., 2015; Colpron and Nelson, 2011; Ershova et al., 2015b,c; Ershova et al., 2016b; Gasser and Andresen, 2013; Hadlari et al., 2014; Lawver et al., 2002; Miller et al., 2010, 2011, Pease and Scott, 2009). Paleogeographic reconstructions of the present day Arctic are complicated by uncertainties in identifying and correlating key tectonic events associated with Early to Middle Paleozoic orogenies.
Poorly resolved evolution of the Amerasian Basin further complicates the reconstruction of pre-Cenozoic tectonics and paleogeography. The affinity of the so-called Kara Terrane, comprising the Severnaya Zemlya archipelago and northern Taimyr in the Russian High Arctic (Fig. 1), is a critical piece of the Early-Middle Paleozoic Arctic jigsaw puzzle.

This paper is dedicated to reconstructing the Arctic's Middle Paleozoic based on (U-Th)/He thermochronologic ages and combined $\mathrm{U} / \mathrm{Pb}$ and (U-Th)/He of detrital zircons collected from Ordovician-Devonian strata in the Severnaya Zemlya archipelago (Fig. 1). (U-Th)/He low temperature thermochronology records the time at which the mineral passes through its closure temperature from $60^{\circ}$ to $300^{\circ} \mathrm{C}$, depending on the system (Farley, 2002; Reiners et al., 2004). The (U-Th)/He system in zircon closes at temperatures of approximately $170-190^{\circ} \mathrm{C}$, which typically occur at $6-7 \mathrm{~km}$ depth beneath the surface in continental crust with a typical geothermal gradient of $30^{\circ} \mathrm{C} / \mathrm{km}$ (Reiners 2005; Wolfe and Stockli 2010). Combined

\footnotetext{
* Corresponding author

E-mail address: v.ershova@spbu.ru (V. Ershova).
} 

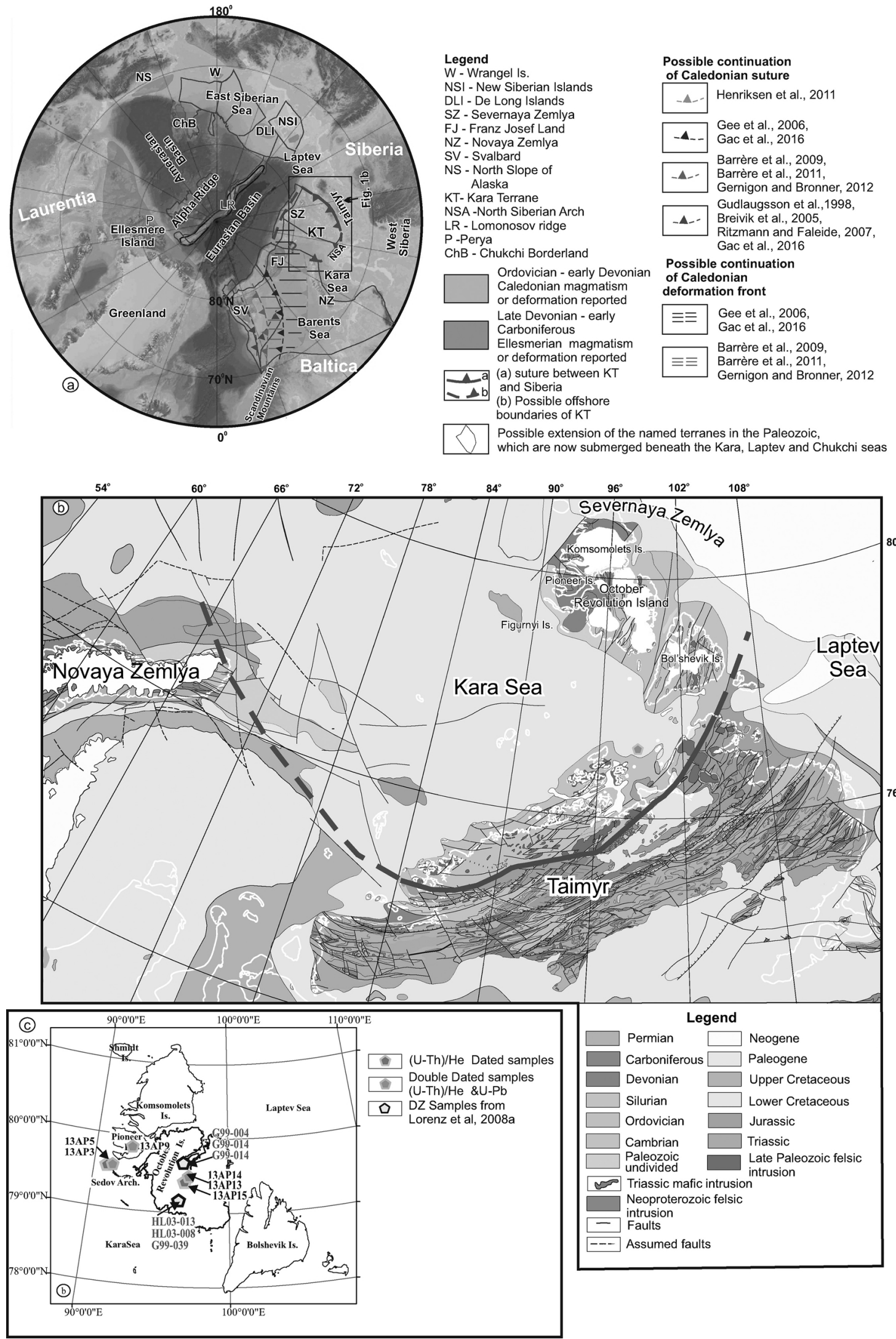

(caption on next page) 


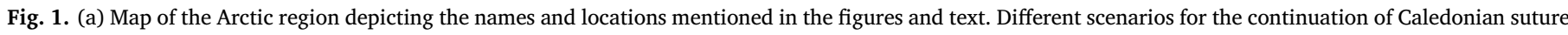

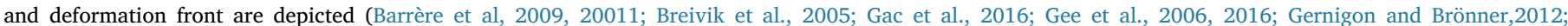

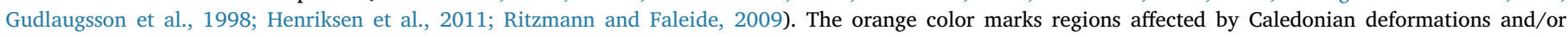

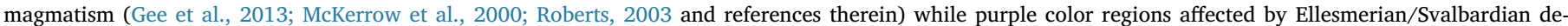

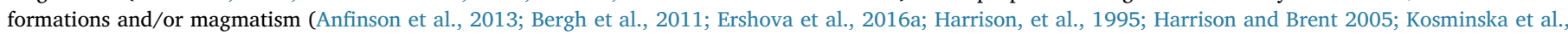

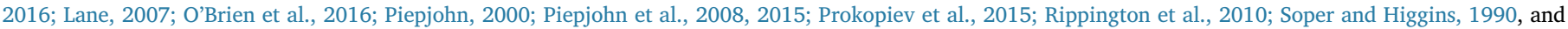

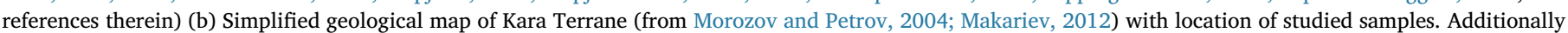

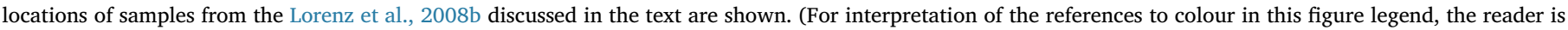
referred to the web version of this article.)

$\mathrm{U} / \mathrm{Pb}$ and $(\mathrm{U}-\mathrm{Th}) / \mathrm{He}$ dating on the same zircon crystal provides both high- and low-temperature ages of detrital grains, corresponding to crystallization (or subsequent high-grade metamorphism) and cooling/ exhumational events respectively. Thus the combination of both crystallization and cooling ages can provide more informed and robust provenance interpretations than is possible by just using a single radioisotopic system (Reiners et al., 2004). The (U-Th)/He thermochronologic data, supplemented with new and existing detrital zircon $\mathrm{U}-\mathrm{Pb}$ ages, offer a new and updated perspective on the Early-Middle Paleozoic exhumation history and subsequent Paleozoic tectonic evolution of the Russian High Arctic, therefore improving our understanding of the paleogeography and tectonics of Kara terrane and neighboring regions.

\section{Early-middle paleozoic tectonic events reported from the arctic}

The paleo-positions of terranes now exposed in the High Arctic are poorly known for the time prior to the opening of the Amerasian and Eurasian oceanic basins (Fig. 1a). Uncertainty largely stems from determination of the age and distribution of Paleozoic orogenic events, evidence of which is now scattered across the Arctic realm. The EarlyMiddle Paleozoic Caledonian Orogen was formed by prolonged Ordovician-late Silurian closure of the Iapetus Ocean, generated by numerous episodes of arc-arc, continent-arc and finally by continent-continent collision between Laurentia and Baltica (e.g. Gee et al., 2013; McKerrow et al., 2000; Roberts, 2003). Presently, fragments of the former Caledonian Orogen have been rifted apart by the opening of the younger oceanic basins, and can be traced from the eastern seaboard of North America to Greenland, Scotland and western Scandinavia. However, its continuation further to the east and north from Scandinavia is debatable due to burial of Early-Middle Paleozoic rocks beneath thick younger sedimentary successions of the Barents Sea basin. Due to this uncertainty, numerous models exist postulating the possible continuation of the Caledonian suture and deformation front offshore within the Barents Sea and beyond (Fig. 1a).

Based on geophysical data, Breivik et al. (2005) proposed two major thrust/suture zones in the western portion of the Barents Sea. The first zone is interpreted as a relic of westward dipping Caledonian continental collision or major thrusting. The basement/Moho trend of the first zone projects onto the Billefjorden Fault Zone on Spitsbergen and is a proposed Caledonian suture that divides Svalbard into two tectonic domains. The second zone extends south from Spitsbergen and has a SW-NE orientation (Breivik et al., 2005). Based on the proposed Laurentian affinity of northeastern Svalbard, both Gee et al. (2006) and Barrère et al. (2011) placed the suture between Svalbard and Franz Josef Land, however Barrère et al. (2011) positioned the suture closer to Svalbard than Gee et al. (2006, 2008). Gravity field data from the Barents Sea was used by Henriksen et al. (2011) to identify two distinct regions, a gravity-high to the west and a gravity-low to the east. From this data, Henriksen et al. (2011) suggested that the main part of the Barents Shelf was deformed as part of the Caledonides, placing the Caledonian suture close to the Novaya Zemlya archipelago. Recent Ar-Ar dating of muscovite from metasedimentary bedrock dredged from the Lomonosov Ridge (Knudsen et al., 2018; Marcussen et al., 2015), indicates that this block was also involved in the Caledonian deformation leading Marcussen et al. (2015) to propose a possible continuation of the suture through the Lomonosov Ridge.

Estimates of the Caledonian deformation front location within the Barents Shelf are also intensely debated (Fig. 1a). Gee et al. (2006) propose that it extends to the east of Svalbard, since eastern Svalbard was intensely deformed during the Caledonian Orogeny. Using Ar-Ar and K-Ar data from a single well penetrating the basement of Franz Joseph Land, that indicate that the basement rocks were also affected by Caledonian deformation, Gee et al. (2006) postulated that the deformation front was located to the east of Franz Joseph Land.

Breivik et al. (2005) imply that almost the entire basement of the Barents Shelf was involved in the Caledonian deformation, whilst re et al. (2009, 2011); and Gernigon and Brönner (2012) suggest that the Caledonian deformation front ends just to the southeast of Svalbard (Fig. 1a). In addition, evidence of Caledonian deformation has been identified in many other remote Arctic locations including Pearya, the Chukchi Borderland, De Long Islands and eastern Greenland (Fig. 1) (Brumley et al., 2015; Gasser, 2014; Gee et al., 2006, 2008; Prokopiev et al., 2015; Roberts, 2003; Trettin, 1987, and references therein).

Tectonic events across the Caledonides group into four major compressive/transpressive stages (Corfu et al., 2014; Roberts, 2003 and references therein). The oldest phase, Trondheim (Early Ordovician), involved collision between Baltica, or an adjacent microcontinent, and Iapetus island arcs. The second phase, the Taconian (Middle - Late Ordovician), was associated with accretion of an island arc to the Laurentian margin. The third phase, the Scandian (Middle Silurian Early Devonian), involved rapid subduction of the Baltican margin beneath Laurentia and culminated in continental collision between Baltica and Laurentia (Roberts, 2003). The final phase, the Solundian or Svalbardian phase (Late Devonian-Early Carboniferous), is primarily described from the onshore Scandinavian Caledonides and Svalbard, but its interpretation and relationship to other events of the Caledonian Orogeny are controversial (Bergh et al., 2011; Eide et al., 2002; Fossen, 2010; Roberts, 2003; Sturt and Braathen, 2001; Torsvik et al., 1986). Some researchers (e.g. Eide et al., 2002; Fossen, 2010; Roberts, 2003) interpret the Solundian phase as an orogenic collapse with widespread extension/transpression. However, Torsvik et al. (1986) and Sturt and Braathen (2001) document compressional deformation and low-grade metamorphism of the same age. In addition, Bergh et al. (2011) describe Late Devonian folding, oblique thrusting and basement uplift in Svalbard, relating these events to the final compressional activity associated with the Caledonian Orogeny.

Roughly coeval to the Solundian/Svalbardian phase is the enigmatic tectonic event commonly referred to as the Ellesmerian Orogeny in many other regions of the Arctic (e.g. Anfinson et al., 2013; Embry, 1988, 1993; Higgins et al., 2000; Lawver et al., 2002). There is evidence of Late Devonian to Early Carboniferous deformation and magmatism reported from the Canadian Arctic Islands, north slope of Alaska, north Yukon, north Greenland, Svalbard, the New Siberian Islands, Wrangel Island and Chukotka (Anfinson et al., 2013; Ershova et al., 2016a; Harrison, 1995; Harrison and Brent, 2005; Gilotti et al., 2004, 2014; Lane, 2007; Lane et al., 2016; O'Brien et al., 2016; Piepjohn, 2000; Piepjohn et al., 2008; Piepjohn et al., 2015; Prokopiev et al., 2015; Rippington et al., 2010; Soper and Higgins, 1990, and references therein) (Fig. 1a). However, there are many uncertainties about tectonic causes, distribution, and consequences of the Ellesmerian Orogeny in the Arctic realm. It has been interpreted to be the result of 


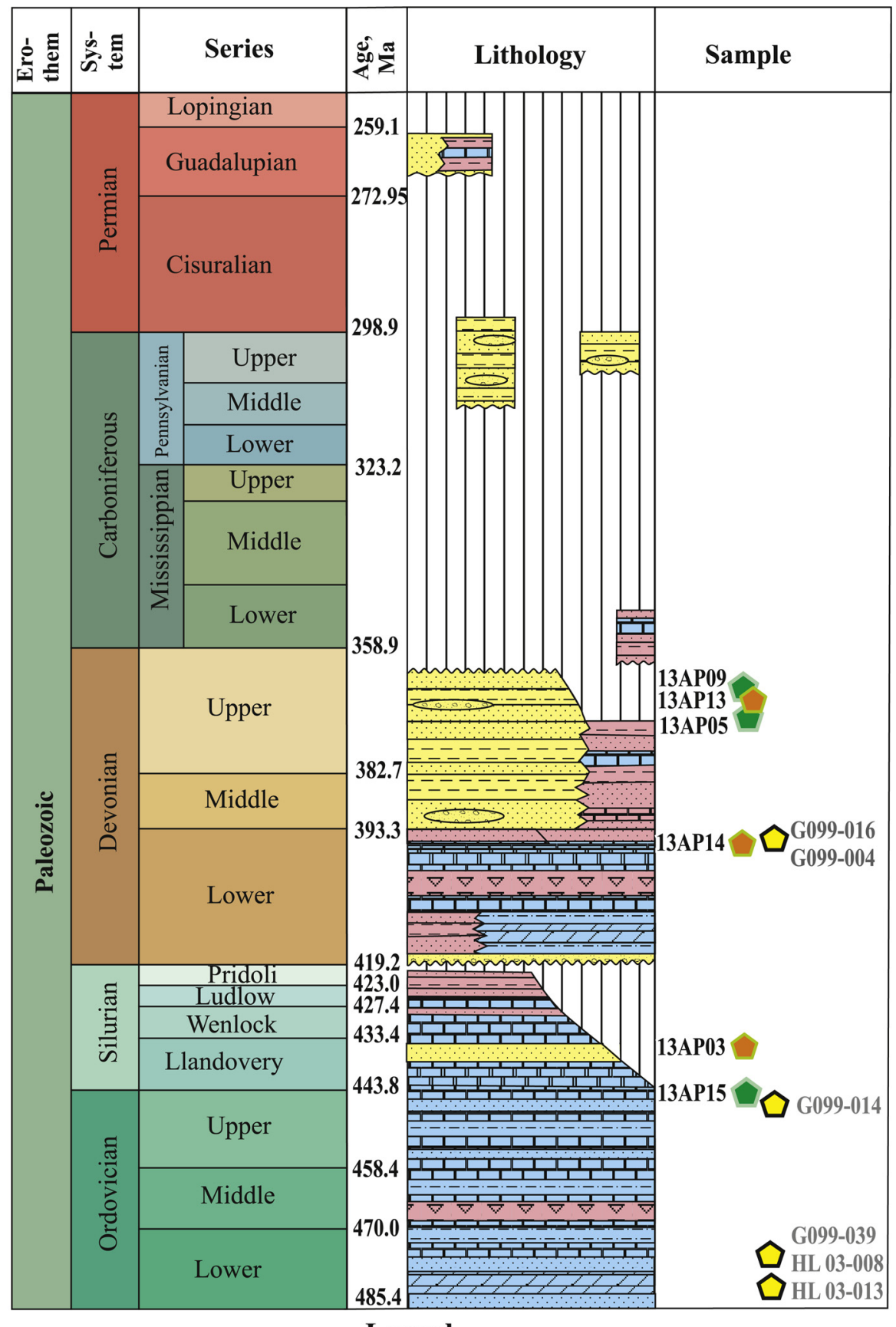

\section{Legend}

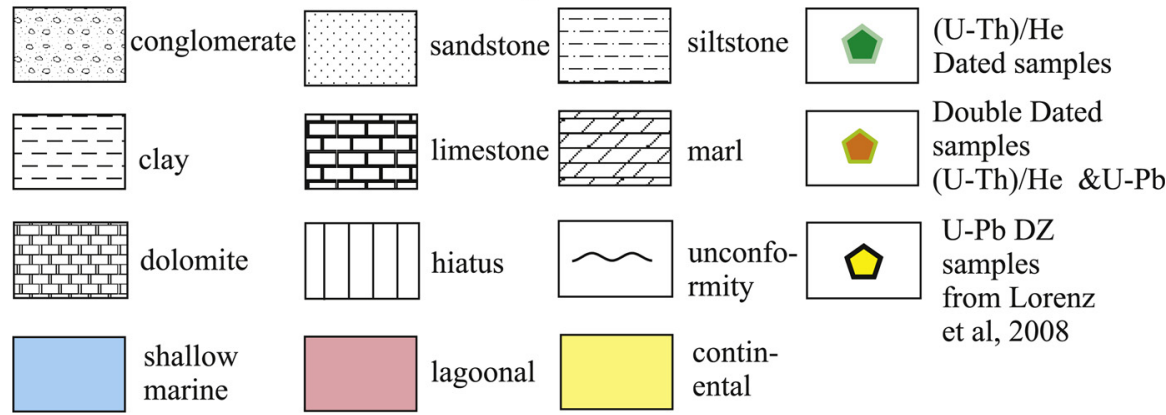

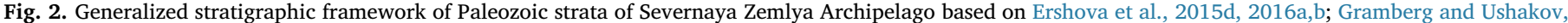
2000; Makariev, 2012; Markovsky et al., 1988; Matukhin and Menner, 1999. Numerical ages from Cohen et al., 2016. 
collision between the Pearya Terrane and Svalbard with the Franklinian Basin of Laurentia (Piepjohn et al., 2015), or between Laurentia and an enigmatic continental block that comprised the Pearya Terrane, Chukotka, Chukchi Borderland, Svalbard, and other Arctic terranes that is commonly referred to as Crockerland (Anfinson et al., 2012; Anfinson et al., 2013; Embry, 1993), and more recently described as being part of the proposed Arctida landmass (Anfinson et al., 2016). Moreover, due to the opening of younger oceanic basins, uncertainty exists regarding whether the Ellesmerian Orogeny and the latest stages of the Caledonian Orogeny represent the same tectonic episode, or whether they were truly separated in time and space. Thus the Late Devonian tectonic episode and metamorphism in Svalbard is correlated to either the terminal stage of the Caledonian Orogeny (Bergh et al., 2011), or the Ellesmerian Orogeny (Kosmiönska et al., 2016; Piepjohn, 2000). More precise temporal correlation is clearly needed between Late DevonianEarly Carboniferous magmatic and tectonic events of the entire Arctic region and those of the Russian Arctic.

\section{Geological background of the Severnaya Zemlya archipelago (Kara terrane)}

The Severnaya Zemlya archipelago comprises four main islands called Pioneer, October Revolution, Komsomolets and Bol'shevik, along with numerous other small islands and island groups such as the Sedov Islands.

Together with the northern part of the Taimyr Peninsula and intervening shelf, it makes up the core of the Kara Terrane, also named Kara Block, Kara Plate or North Kara Terrane (KT on Fig. 1a) (Drachev et al., 2010; Lorenz et al., 2008a). The northeastern boundary of the Kara Terrane corresponds to the margin of the continental shelf of the Cenozoic Eurasia Basin. Towards the south, the Kara Terrane abuts central Taimyr and Siberia along the Main Taimyr Thrust and Diabazoviy Fault respectively (Vernikovsky, 1996). To the southwest, it is likely separated from the South Kara Basin and West Siberia by the linear North Siberian Arch (Drachev et al., 2010). The continuation of the Kara Terrane northwest of the North Siberian Arch is debated.

Paleomagnetic data seem to suggest that the Kara Terrane was an isolated crustal block throughout the Paleozoic (Metelkin et al., 2000). The NW-SE orientation of the structural high separating the eastern Barents Sea and the northern Kara Sea (Kara Terrane), is imaged by geophysical data and illustrated by the 3D model of Klitzke et al. (2015), and is likely to correlate with the Timanide suture. This high is therefore assumed to mark the collision between the Kara Terrane and Baltica during the Timanian Orogeny in the latest Neoproterozoic (Klitzke et al., 2015; Lorenz et al., 2008a). Based on seismic data, Paleozoic strata of the northeastern part of the Barents Sea can be traced into the North Kara Basin (Daragan-Suschova et al., 2013), supporting ideas that the Kara Terrane was attached to Baltica during most of the Paleozoic. Furthermore, based on the continuity of magnetic anomaly data patterns, Gee et al. (2006) suggest that the Kara Terrane can be extended into northern Novaya Zemlya and represents an integral part of Baltica (Lorenz et al., 2008a,b). However, defining the eastern boundary of the Kara Terrane is severely hampered by Meso-Cenozoic rifting of the Laptev Shelf prior to opening of the Eurasia Basin.

Several different tectonic models consider the tectonic affinity of the Kara Terrane. According to Zonenshain et al. (1990), during the Paleozoic this terrane was part of a larger continental block called Arctida. Lorenz et al. (2008b) suggest that the Kara Terrane was a marginal part of Baltica, whilst other researchers (Bogdanov et al., 1998; Gramberg and Ushakov, 2000; Metelkin et al., 2000) suggest the Kara Terrane was an independent terrane or microcontinent during the Paleozoic. A number of previous detrital zircon studies suggested that the terrane was a marginal part of Baltica during the Early-Middle Paleozoic (Ershova et al., 2015a,b,c,d; Lorenz et al., 2008b; Pease and Scott, 2010).

\section{Stratigraphy of Severnaya Zemlya archipelago}

The Paleozoic stratigraphy of the Severnaya Zemlya archipelago comprises Cambrian to Permian sedimentary deposits (Ershova et al., 2015d, 2016a; Gramberg and Ushakov, 2000; Makariev, 2012; Matukhin and Menner, 1999 and references therein). The Pioneer, October Revolution and Komsomolets islands are mainly comprised of Cambrian to Upper Devonian deposits with locally distributed Carboniferous and Permian strata. Predominantly Cambrian-Ordovician deposits are exposed on Bol'shevik Island, with a few outcrops of Upper Carboniferous-Permian and Mesozoic deposits (Makariev, 2012) (Fig. 2). The lateral continuity and facies of the sedimentary succession are quite variable across the archipelago (for a more detailed description of the stratigraphy see Ershova et al., 2016a.

The Cambrian strata are represented by alternating varicolored sandstones, siltstones, and marls with subordinate beds of limestone, which have thickness ranging from 1000 to $2000 \mathrm{~m}$. According to Lorenz et al. (2007), an angular unconformity separates overlying Ordovician strata from Cambrian deposits. However, according to others (Makariev, 2012; Markovsky et al., 1988), this boundary is a disconformity. Ordovician deposits comprise two distinct successions, the Lower to lowest Middle Ordovician succession is mainly represented by alternating sandstones, clays, and siltstones with subordinate beds of carbonate and a few volcanic tuffs at the base (Lorenz et al., 2007; Makariev, 2012). The Middle-Upper Ordovician succession is comprised primarily of limestone with subordinate beds of clastic beds and evaporites. The approximate thickness of the Ordovician strata ranges from 650 to $1400 \mathrm{~m}$. Silurian deposits lie conformably on the Ordovician, comprising $700-1100 \mathrm{~m}$ of Llandoverian-Ludlovian carbonates and marls, overlain by up to $700 \mathrm{~m}$ of Pridolian interbedded shales, rare sandstones and carbonates (Matukhin and Menner, 1999).

The Lower Devonian deposits are disconformably overlain by different levels of Silurian deposits and comprise up to $600 \mathrm{~m}$ of carbonates and evaporites, with beds of shales and sandstones in the lower part of succession (Makariev, 2012; Matukhin and Menner, 1999). The Middle to Upper Devonian succession is typically $1000-1500$ m thick and is comprised of continental red-colored sandstones and siltstones with subordinate beds of gravelly- to pebbly-conglomerates (Makariev, 2012). Carboniferous-Permian deposits are sparsely distributed across the archipelago and consist of continental clastics up to a few hundred meters in thickness (Ershova et al., 2015d; Makariev, 2012).

\section{Overview of previous provenance studies from the paleozoic rocks of the Severnaya Zemlya archipelago}

Previous provenance studies have revealed that Cambrian strata within the archipelago have two main detrital zircon age groups. The younger age group consists of 500-600 Maa zircons and is likely derived from the Timanian Orogen (Lorenz et al., 2008b; Ershova et al., 2015a). The older age groups, ranging from ca. 0.9-1.2 Ga and 1.4-1.8 Ga, are attributed to the Sveconorwegian-Grenvillian Orogen and the basement of Baltica respectively. Ordovician deposits contain many of the same detrital zircon ages as the Cambrian strata, but also contain a primary age group of $450-500 \mathrm{Ma}$ (Lorenz et al., 2008a). Lorenz et al. (2008a) suggested that the Ordovician grains are sourced from local magmatic units exposed in the Severnaya Zemlya archipelago. However, the significant thickness of Ordovician strata (up to $2000 \mathrm{~m}$ ) and its broad distribution across almost the entire archipelago suggest that an alternative source of clastic sediment is also viable.

Lorenz et al. (2008a) document the prominent shift in detrital zircon age spectra between pre-Devonian and Devonian strata. Within the Devonian deposits, Precambrian detrital zircons are dominated by Sveconorwegian-Grenvillian (0.9-1.2 Ga) and Baltica basement $(1.4-1.8 \mathrm{Ga})$ age groups. Upper Carboniferous to Lower Permian sandstones however contain a primary age group ranging from 450 to $570 \mathrm{Ma}$, with a predominance of Early-Middle Ordovician zircons 
(Ershova et al., 2015d). The detrital zircon age distributions suggest that the Upper Carboniferous to Lower Permian sandstones were derived locally from the erosion of Lower Ordovician deposits (Ershova et al., 2015d). The temporal variability in geochronologic ages within the archipelago suggests a complex tectonic history in the provenance area and warrant analysis of the exhumation history by thermochronologic techniques, which are lacking for the region to date. The recent $\mathrm{U}-\mathrm{Pb}$ detrital zircon studies of the Lower-Middle Paleozoic rocks across the Russian High Artic revealed many similarities between the provenance areas of clastics in Novaya Zemlya, Severnaya Zemlya, and the New Siberian Islands (Ershova et al., 2015a,b,c, 2016a,b; Lorenz et al., 2008a,b; Lorenz et al., 2013). The principal conclusion from these studies was that these now geographically separated regions belonged to the marginal part of Baltica during the Early-Middle Paleozoic.

\section{Methods}

Detrital zircon (U-Th)/He analyses were performed on six samples within the Severnaya Zemlya archipelago. Additional detrital zircon double dating (U-Pb and (U-Th)/He) ages were performed on three of the samples to provide additional geochronologic constraints. Samples were crushed and the heavy minerals were concentrated using standard techniques at the Institute of Precambrian Geology and Geochronology, Russian Academy of Sciences. (U-Th)/He and U-Pb dating of detrital zircons was carried out at the UTChron geochronology facility in the Department of Geosciences at the University of Texas, Austin. All U-Pb LA-ICPMS detrital zircon analyses were performed on whole grain mounts (instead of polished mounts) to preserve the grains for (U-Th)/ He analyses. LA-ICPMS instrument parameters and expanded data reduction methods can be found in the Supplementary File 1. For grains older than $1.0 \mathrm{Ga}$, the $207 \mathrm{~Pb} / 206 \mathrm{~Pb}$ age is reported, while for grains younger than $1.0 \mathrm{Ga}$, the $206 \mathrm{~Pb} / 238 \mathrm{U}$ age is selected. Following $\mathrm{U}-\mathrm{Pb}$ analyses, selected grains were chosen for additional (U-Th)/He analyses. Specific grains that were at least $70 \mu \mathrm{m}$ in diameter were chosen, and they appeared to have few, if any, visible inclusions, and were Ordovician or older in age. Due to the detrital nature of the samples and potential dispersion in (U-Th)/He cooling ages, up to 13 single grains/ per sample were analyzed for some samples, leading to a total of 41 analyses. Analyses were conducted following analytical procedures described in Wolfe and Stockli (2010) and a brief description of these methods can be found in Supplemental File 1. All ages were corrected for the effects of $\alpha$-ejection (Farley et al., 1996) and are reported with a $\sim 8 \%(2 \sigma)$ analytical uncertainty. Detailed analytical methodology, detrital zircon $\mathrm{U}-\mathrm{Pb}$ analytical results, and (U-Th)/He analytical results are provided in Supplemental Files 1, 2 and 3, respectively.

\section{Results of detrital zircon (U-Th)/He dating}

Six samples with depositional ages ranging from Ordovician to Devonian were analyzed for detrital zircon (U-Th)/He geochronology. All obtained ages are older than the depositional ages of the host strata, indicating that the samples were not buried deeply enough $(>7 \mathrm{~km})$ to reset the isotopic system. Therefore, the ages can be reliably interpreted to indicate the exhumation history within the source region of the clastic material (Fig. 3a,b).

Sample 13AP15 is an Upper Ordovician fine- to medium-grained sandstone collected from the Matusevich River of October Revolution Island (Figs. 1, 2), whilst sample 13AP03 is a Lower Silurian fine- to medium-grained sandstone from Figurnyi Island (Figs. 1, 2). Eleven detrital zircon grains from the two samples yield (U-Th)/He ages ranging from $583.8297 \pm 46.7$ to $429.0 \pm 34.3 \mathrm{Ma}$ (Fig. 3a), with a peak age at ca. $465 \mathrm{Ma}$ (Fig. 3c).

Combined (U-Th)/He and $\mathrm{U}-\mathrm{Pb}$ dating of zircons from Upper Ordovician strata (13AP15) indicate that some of the Latest Neoproterozoic (U-Pb age) zircons were partially reset during the Caledonian Orogeny, whilst some of them retained their initial uplift/ cooling ages (Fig. 3b).

Four Devonian samples were selected for detrital zircon (U-Th)/He dating. Sample 13AP05 was collected from Frasnian medium-grained sandstones on Figurnyi Island (Figs. 1, 2), whilst sample 13AP09 was collected from Upper Devonian (Frasnian-Famennian) medium-grained sandstones on Pioneer Island. Sample 13AP13 was collected from medium- to coarse-grained Frasnian sandstones on October Revolution Island (Matusevich River), whilst sample 13AP14 was collected from late Early Devonian fine- to medium-grained sandstones from the same locality (Figs. 1, 2).

In the Devonian strata, thirty detrital zircon grains from four samples yielded $(\mathrm{U}-\mathrm{Th}) / \mathrm{He}$ ages ranging from $517.2 \pm 41.38$ to $332.9 \pm 26.6 \mathrm{Ma}$ (Fig. 3a). In contrast to the older (Ordovician-Silurian) clastic rocks, (U-Th)/He ages from the Devonian deposits have a main age peak at ca. $375 \mathrm{Ma}$ (Fig. 3c). A subordinate zircon population shows a peak age of ca. $465 \mathrm{Ma}$ (Fig. 3b), equivalent to the age peak in older Ordovician-Silurian clastic rocks.

The combined U-Pb and (U-Th)/He dating of Devonian sandstones depicted in Fig. 3b suggest that detrital zircons that crystallized in the Cambrian and Precambrian (U-Pb ages) were subsequently exhumed in the Middle Ordovician and Late-Devonian ((U-Th)/He ages).

\section{Discussion}

The obtained detrital zircon (U-Th)/He ages have not been reset since deposition, constraining the maximum burial of the studied succession to $<\sim 7 \mathrm{~km}$. The detrital zircon (U-Th)/He ages indicate two distinct source regions for the Ordovician-Silurian and Devonian clastic sedimentary rocks of Severnaya Zemlya. The (U-Th)/He detrital zircon ages from Ordovician- Silurian strata show a primary age peak at ca. $465 \mathrm{Ma}$ (Fig. 3c) which, within error, can be attributed to the early orogenic episodes reported from the Scandinavian Caledonides (Roberts, 2003). The (U-Th)/He data correlate well with previously published U-Pb ages of detrital zircons from the Ordovician rocks of Severnaya Zemlya (Lorenz et al., 2008b), which contain prevailing Late Cambrian-Ordovician zircons including the main population grouped at ca. $462 \mathrm{Ma}$ (Fig. 3d), along with minor populations at $530 \mathrm{Ma}$ and ca. $600 \mathrm{Ma}$. Furthermore, the similarity of the U-Pb and (U-Th)/He ages indicate that shortly after crystallization there was likely rapid exhumation of magmatic complexes, typical of an active margin setting (ex. Spikings and Simpson, 2014). However, the $465 \mathrm{Ma}$ ages correspond to arc-continent, and not continent-continent collision, within Caledonian orogen (Roberts, 2003). Moreover, the comparison between data presented here and $\mathrm{Ar}-\mathrm{Ar}$ cooling ages from different regions affected by Caledonian deformation (Fig. 4) shows that this 465 Ma event is more clearly seen in Svalbard and Greenland rather than in Scandinavian Caledonides. However, earlier pre-Scandian exhumational phases were likely overprinted by a Scandian event within Caledonian orogen, which corresponds to the main pulse of continent-continent collision. Thus, the (U-Th)/He ages presented here and U-Pb data of detrital zircon from Lorenz et al. (2008a,b) clearly indicate extensive tectono-magmatic activity in the Middle-Late Ordovician within the source region of studied clastic rocks. Thus, our data favor the PeriBaltica model for the affinity of the Kara Terrane proposed by Lorenz et al. (2008a,b), suggesting that clastics have been sourced from northeastern part of Baltica (modern coordinates). Moreover, double dating of detrital zircon indicate that detrital zircons crystallized during the Timanian Orogeny (U-Pb ages $680-560 \mathrm{Ma}$ ) were partially reset during the Caledonian Orogeny ((U-Th)/He ages of 455-495 Ma) in the source area, suggesting that within the source region, the Timanian Orogen was likely overprinted by Caledonian exhumational events. We therefore suggest that the primary source area of these sediments, is an Ordovician continental arc built on Timanian-age crust. The arc was part of the active Margin of the Iapetus Ocean, and its remains are presently located within the modern Arctic Ocean. Although much of the source region for these sediments is now likely submerged as part of 

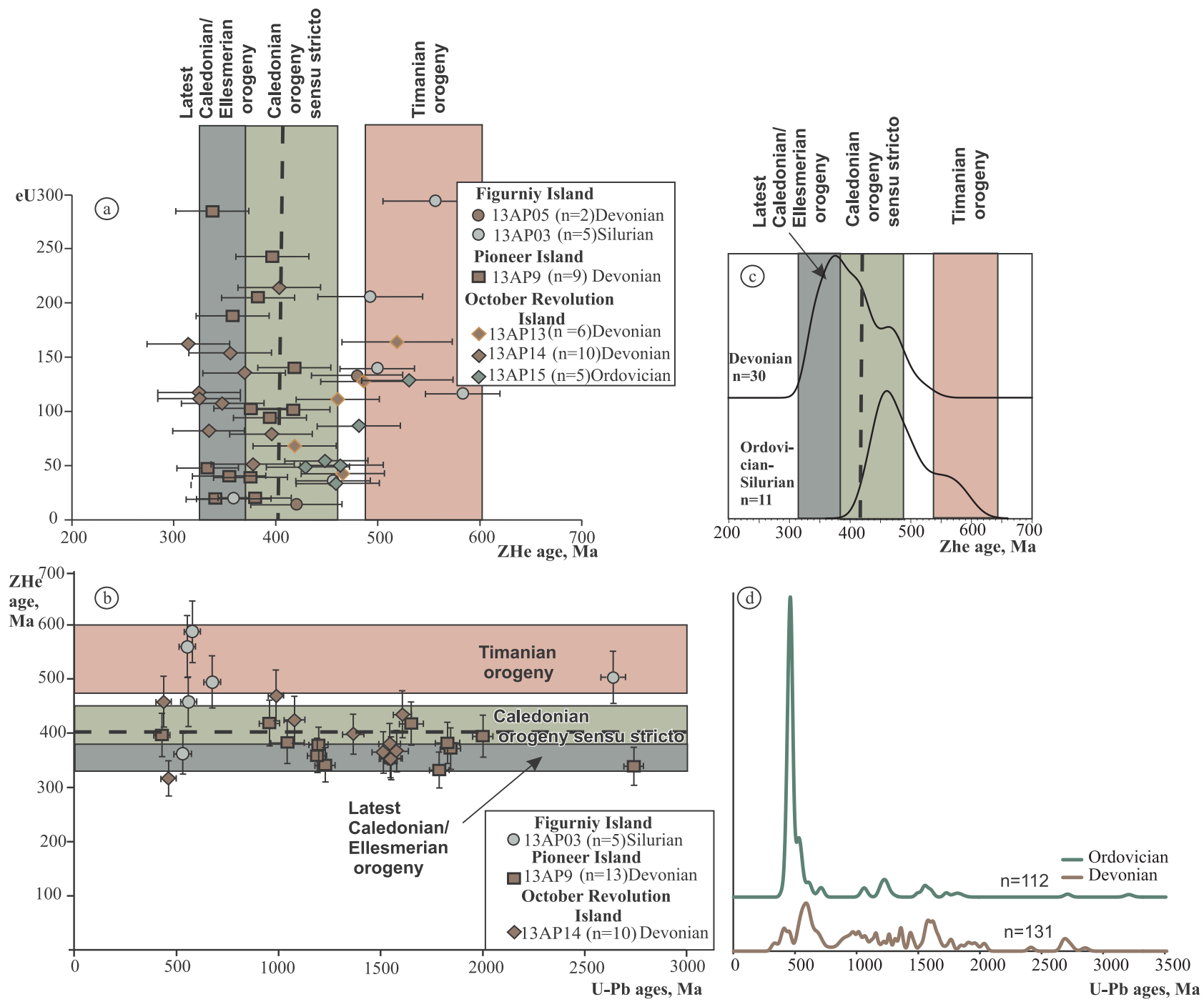

Fig. 3. Detrital zircon (U-Th)/He and U-Pb age data. (a) (U-Th)/He ages of zircons (ZHe) plotted against effective uranium concertation (e(U), depicting that there is no significant influence of e(U) on the (U-Th)/He ages, (b) - Double-dated (U/Pb and (U-Th)/He) zircons, (c) Relative probability plots of (U-Th)/He ages from Ordovician-Silurian and Devonian samples; $n$ is the number of (U-Th)/He ages, (d) - U-Pb age populations from the Ordovician and Devonian strata after Lorenz et al. (2008b). ZHe data from Devonian sandstones are all represented by markers filled with dark brown, whereas the older samples are represented by markers filled with dark and light green. The shaded bars indicate the main orogenic events that affected the provenance area of the studied clastics. The ZHe ages for OrdovicianSilurian rocks suggest Caledonian and Timanian sources for clastics, furthermore combined $\mathrm{U} / \mathrm{Pb}$ and (U-Th)/He dating show that within the source region, the Timanian Orogen was likely overprinted by younger Caledonian events. Devonian samples revealed that the source region was affected the Ellesmerian Orogeny or the terminal Solundian/Svalbardian stages of the Caledonian Orogeny.

the Amerasian and Eurasian basin continental shelves, there are a few on-shore localities that contain evidence of a similar geologic history. For instance, the basement of the Franz Josef Land archipelago (northeastern Barents sea; Fig. 1), contains Ar-Ar cooling ages suggesting Latest Neoproterozoic-Cambrian (?) deposits experienced a Caledonian metamorphic event (Pease et al., 2001). Within the De Long Islands (part of the New Siberian Islands Archipelago in the Russian Eastern Arctic), one can find Timanian-age basement (Ershova et al., 2016a,b) which experienced significant uplift and exhumation in the EarlyMiddle Palaeozoic (Prokopiev et al., 2015). Thus, there is growing evidence that indicates Timanian age basement within the Arctic realm, that was potentially part of the Early Paleozoic northern margin (modern coordinates) of the Baltica paleocontinent, and experienced younger Caledonian orogenic events.

Furthermore, recent Ar/Ar dating of metamorphic muscovite from the arkosic metasedimentary rock dredged from the Lomonosov Ridge indicates that a metamorphic pulse was associated with an orogenic event around $470 \mathrm{Ma}$, which could be correlated with the early stages of the Caledonian Orogeny (Marcussen et al., 2015, Knudsen et al., 2018). The age of the metamorphic event on the Lomonosov Ridge is similar, within error, to the $465 \mathrm{Ma}$ exhumation event recorded within the provenance area for the Ordovician-Silurian successions of Severnaya Zemlya presented here. The data presented here is close in the exhumation-age reported from the basement of Franz Joseph land and Lomonosov ridge suggest that the rocks involved in the Caledonian Orogeny and/or deformation front affected most of the Barents Shelf including its northeastern part. It also indicates that the deformation front may have also extended further to the north and affected the Lomonosov Ridge. This part of Caledonian orogen likely represented the main provenance for studied Ordovician-Silurian clastics. These findings are in good agreement with recent models, which suggest, based on geophysical data, that the main suture of the Caledonian Orogen is close to the Franz Josef Land and Novaya Zemlya archipelagoes (Gac et al., 2016; Gee et al., 2006).

The change in provenance from pre-Devonian to Devonian successions is notable in both the detrital zircon (U-Th)/He and U-Pb data 


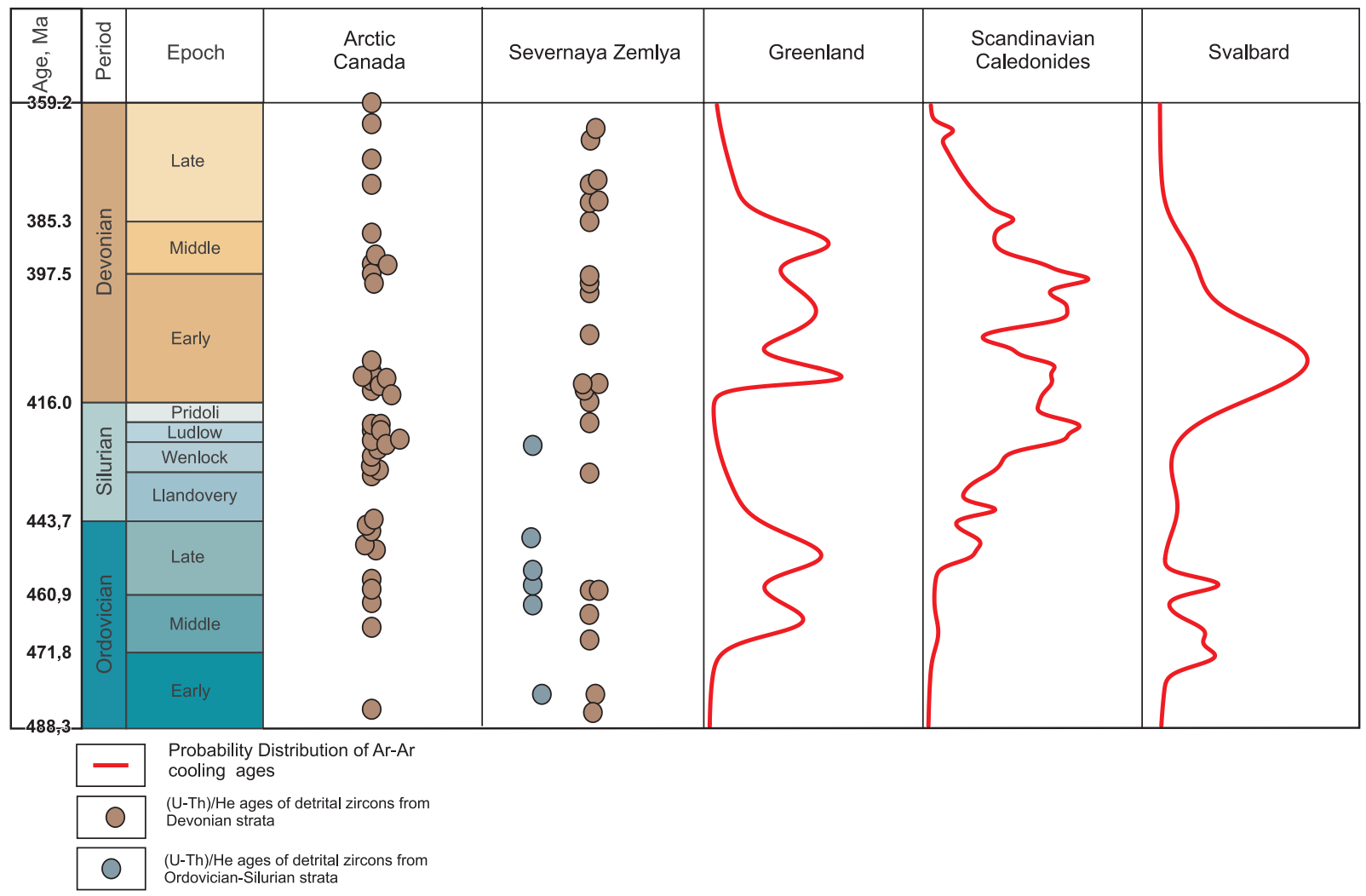

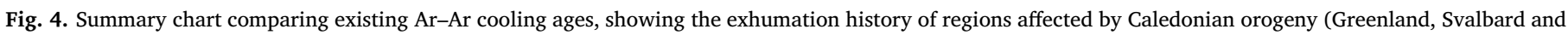

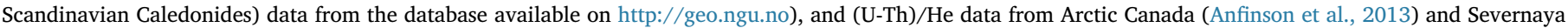
Zemlya Archipelago (this study).

(Lorenz et al., 2008b). Lorenz et al. (2008b) note that in the Devonian deposits the detrital zircon populations are dominated by Mesoproterozoic ages, with typical age peaks around $1600 \mathrm{Ma}, 1450 \mathrm{Ma}, 1250 \mathrm{Ma}$ and $1050 \mathrm{Ma}$, and Neoproterozoic ages grouped at ca. 570, 600 and $980 \mathrm{Ma}$ (Fig. 3d), whilst Caledonian zircons as well as younger zircons that are close to the age of sedimentation are rare. Thus, based on U-Pb ages of detrital zircons, Lorenz et al. (2008b) assumed that the source region of Devonian clastics was uplifted pre-Caledonian basement of the Grenvillian-Sveconorwegian Orogeny, suggesting its continuation further to the north (Lorenz et al., 2008b, 2012). Detrital zircon (U-Th)/ He ages suggest that multiple episodes of tectonic uplift occurred in the clastic source area for Devonian sandstones of Severnaya Zemlya. The minor, ca. 465 detrital zircon (U-Th)/He age peaks, may be correlated to episodes of arc-continent collision within Caledonides (Corfu et al., 2014; Gee et al., 2008; Roberts, 2003,) (Fig. 3c). The dominance of Late Devonian ( $\sim 375 \mathrm{Ma})$ (U-Th)/He ages correlate well with the timing of the Ellesmerian Orogeny or the Solundian/Svalbardian phase of Caledonian deformation (Anfinson et al., 2013; Eide et al., 2002; Lane, 2007; Lane et al., 2016; O’Brien et al., 2016; Rippington et al., 2010; Roberts, 2003; Piepjohn, 2000; Piepjohn et al., 2008). The combined U$\mathrm{Pb}$ and (U-Th)/He dating approach depicted in Fig. 3b suggests that detrital zircons crystallized in the Cambrian and Precambrian were subsequently exhumed during the terminal Early-Middle Paleozoic orogenic events. Hence, in conjunction with recent evidence from many localities across the Arctic, this data provides further evidence for a major orogenic event of Late Devonian-Early Carboniferous age (Ershova et al., 2017a,b; Harrison, 1995; Harrison and Brent 2005; Lane, 2007; Piepjohn et al., 2015; Prokopiev et al., 2015; Rippington et al., 2010; Kosmínska et al., 2016, and references therein). In addition, recent $\mathrm{U}-\mathrm{Th}-\mathrm{Pb}$ monazite dating of metapelites obtained by Kosmínska et al. (2016) show evidence for Ellesmerian age metamorphism within the crystalline basement of Svalbard, with an early prograde stage at ca. $370 \mathrm{Ma}$. Thus, Svalbard was assembled as a whole and positioned north of the main Laurentia-Baltica collision zone by Silurian-early Devonian (Gasser, 2014). Our data from the Devonian deposits of Severnaya Zemlya corresponds well with the recent findings in Svalbard, suggesting the exhumation of older rocks in the Late Devonian in the provenance area. Therefore, this is an additional line of evidence for considering the Kara Terrane as a marginal part of the Baltica continent during the Early-Middle Paleozoic.

So far, neither published data nor data presented here provide concrete evidence that the Late Devonian event could be considered either as a discrete tectonic event (Ellesmerian Orogeny) or belonging to the terminal stages of the Caledonian Orogeny. However, our data could be used as evidence that the Caledonian Orogeny sensu stricto was overprinted by a Late Devonian Ellesmerian or Solundian/ Svalbardian tectonic event (Fig. 4b). Moreover, (U-Th)/He dating of detrital zircon from the Devonian strata of Artic Canada (Anfinson et al., 2013) show similar ages of exhumation (Fig. 4), providing additional evidence of widespread Late Devonian exhumation in Arctic Realm. Taking into account the broad distribution of Late Devonian-Early Carboniferous deformation, felsic magmatism, and metamorphism across the now disparate Arctic terranes (Fig. 1), we propose that terrane accretion and collisional processes are primarily responsible for tectonic events of this age. However, we speculatively suggest that this juxtaposition of continental scale terranes in Late Devonian likely represented the final northward propagation (in present day coordinates) of collision between Laurentia and a marginal region of Baltica (Fig. 5). Recent data on the potential Baltican origin of now separated Arctic terranes from the Russian Arctic-Severnaya Zemlya Archipelago, New Siberian Islands and Chukotka, including Wrangel Island (Lorenz et al., 2008b; Ershova et al., 2015a,b,c; Ershova et al., 2016a,b; Miller et al., 2010), accompanied by reported evidence of Late Devonian deformation within those regions (Prokopiev et al., 

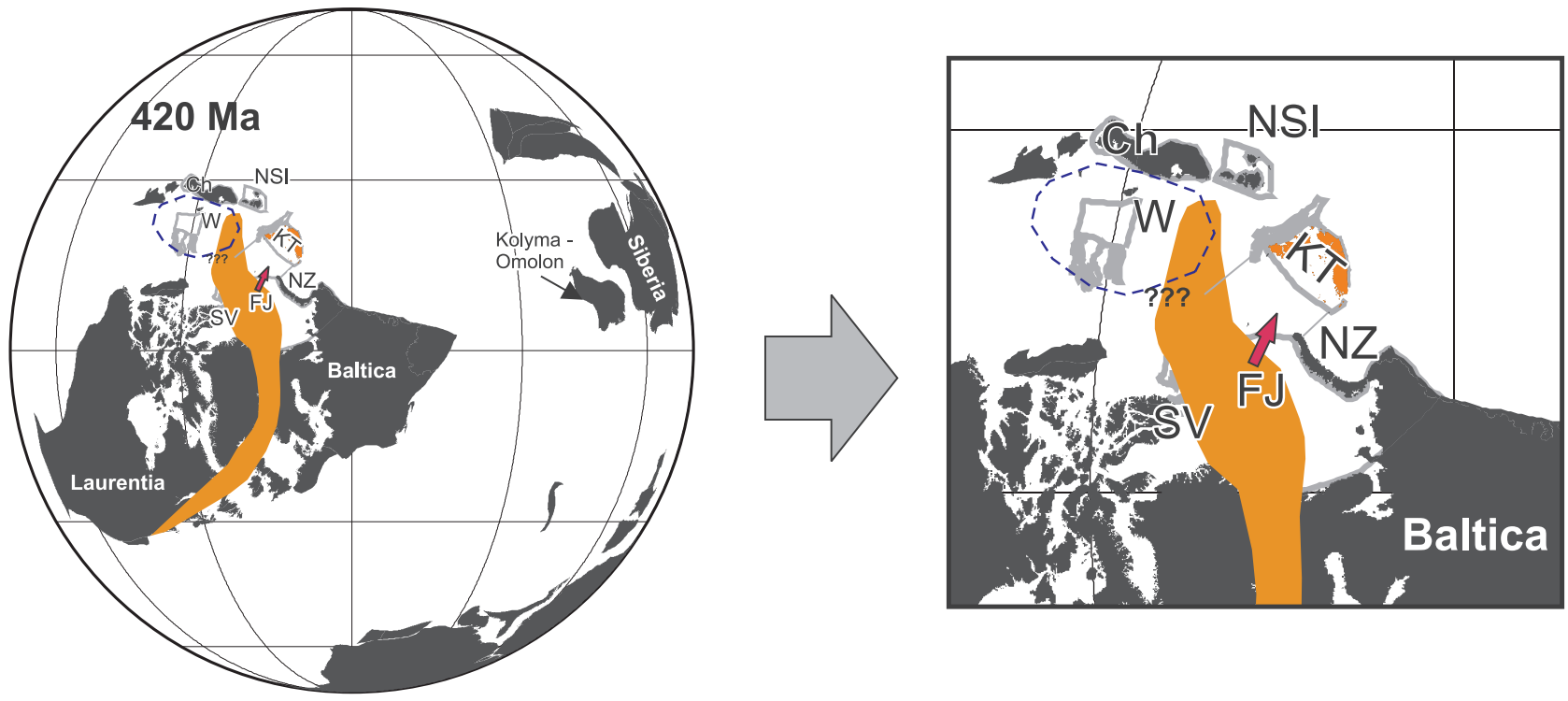

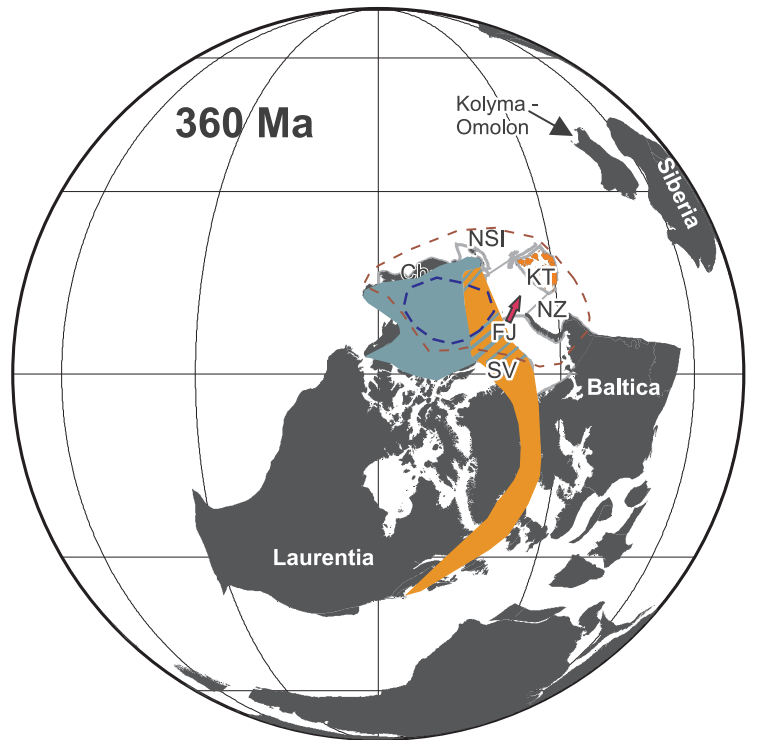

Areas affected by

caledonian orogeny

svalbardian /ellesmerian orogeny

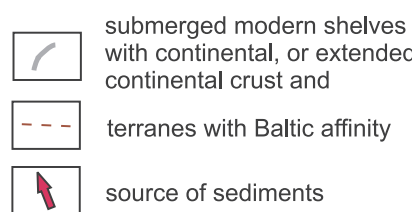

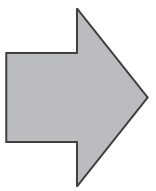

W - Wrangel Is.

NSI - New Siberian Islands

FJ - Franz Josef Land

NZ - Novaya Zemlya

SV - Svalbard

KT- Kara Terrane

(Severnaya Zemlya \&

Northern Taimyr)

Fig. 5. The proposed Artic model for Late Silurian (a) and Late Devonian (b), (modified after Anfinson et al. (2012, 2013); Beranek et al. (2013); Ershova et al. (2015a,b, 2016a,b); Lane et al., 2016; Lawver et al. (2002); Lorenz et al. (2008a,b); Miller et al. (2010, 2011) and references therein); constructed with GPlates opensource software (www.gplates.org). Grey lines illustrate the possible extent of the named terranes in the Paleozoic, terranes which are now submerged beneath the Kara, Laptev and Chukchi seas. Late Mesozoic-Cenozoic extension further complicates the interpretation of Paleozoic terranes boundaries across these shelves. The red dashed line highlights terranes with a Baltica affinity (based on Ershova et al., 2015a,b, 2016a,b; Lorenz et al., 2008a,b; Miller et al., 2010). The outlines are based on present day configuration (therefore no stretching or other deformations have been taken into account). The blue, dashed line highlights the area likely affected by significant extension (up to hyperextension) in Late Mesozoic (ex. Drachev et al., 2010). A more details reconstruction of this region cannot be done due to limited seismic and lack of well data. (For interpretation of the references to colour in this figure legend, the reader is referred to the web version of this article.)

2015; Verzhbitsky et al., 2015), lends additional support to our proposed model.

Further work is needed to address the complex puzzle of Late Devonian-Early Carboniferous tectonics within the Arctic tectonic blocks and to correlate the tectonic and magmatic activities back to a well-defined orogenic event.

\section{Conclusions}

The detrital zircon (U-Th)/He ages from Ordovician-Devonian strata of the Severnaya Zemlya archipelago are older than the depositional age of the host sediments and have not been reset since deposition. Consequently, the studied succession has not been buried beneath a thick succession of younger sediments and lacks any indication of rapid exhumation during the Paleozoic. 
Dual U-Pb and (U-Th)/He geochronology supports previous U-Pb detrital zircon studies (Lorenz et al., 2008b), indicating two distinct source regions for Ordovician-Silurian and Devonian clastics. The (UTh)/He detrital zircon ages from Ordovician-Silurian strata suggest the primary source region was located within the Caledonian and Timanian orogens. Furthermore, the combined U-Pb and (U-Th)/He dating on the same zircon crystal demonstrates that within the source region, the Timanian Orogen was likely overprinted by younger Caledonian events. The obtained detrital zircon (U-Th)/He ages suggest that the clastic source area for the Devonian sandstones was affected by multiple stages of uplift. The oldest stage (Ordovician) corresponds to the Caledonian Orogeny, and the youngest (Late Devonian) to the Ellesmerian Orogeny or the terminal Solundian/Svalbardian stages of the Caledonian Orogeny. That supports the tectonic model proposed by Lorenz et al. (2008a,b), suggesting that the Kara Terrane formed a marginal part of Baltica in the Early-Middle Paleozoic and received clastics from its northeastern part (modern coordinates).

The 375 Ma event revealed from the (U-Th)/He data, in conjunction with recent evidence of coeval tectonic deformation, felsic magmatism and metamorphism reported from many localities across the Arctic, lead us to suggest that juxtaposition of continental scale terranes in Late Devonian likely represented the final northward propagation (in present day coordinates) of collision between Laurentia and a marginal region of Baltica.

\section{Acknowledgments}

This research was supported by RFBR grant 16-55-20012 \& the Research Council of Norway grant 254962/H30, RCN project- Changes at the Top of the World through Volcanism and Plate Tectonics: A Norwegian-Russian-North American collaboration in Arctic research and education: NOR-R-AM (no. 261729). Fieldwork of Victoria Ershova and Andrei Prokopiev in 2013 was supported by Rosneft Co. Interpretation of thermochronological data was supported by the Russian Science Foundation grant No 17-17-868 01171. We are very grateful to the crew of the Somov icebreaker for assistance in the field and hospitality. Thanks to the UTChron geoanalytical staff and the University of Texas at Austin for laboratory support. CG acknowledges support from the Research Council of Norway through its Centres of Excellence funding scheme, project number 223272. Constructive reviews by two anonymous reviewers and the editor significantly improved the manuscript.

\section{Appendix A. Supplementary data}

Supplementary data associated with this article can be found, in the online version, at https://doi.org/10.1016/j.jog.2018.02.007.

\section{References}

Anfinson, O.A., Leier, A.L., Gaschnig, R., Embry, A.F., Dewing, K., 2012. U-Pb and $\mathrm{Hf}$ isotopic data from Franklinian Basin strata: insights into the nature of Crockerland and the timing of accretion, Canadian Arctic Islands. Can. J. Earth Sci 49 (11), 1316-1328.

Anfinson, O.A., Leier, A.L., Dewing, K., Guest, B., Stockli, D.F., Embry, A.F., 2013. Insights into the Phanerozoic tectonic evolution of the northern Laurentian margin: detrital apatite and zircon (U-Th)/he ages from Devonian strata of the Franklinian Basin, Canadian Arctic islands. Can. J. Earth Sci. 50 (7), 761-768.

Anfinson, O.A., Embry, A.F., Stockli, D.F., 2016. Geochronologic constraints on the Permian-Triassic northern source region of the Sverdrup Basin, Canadian Arctic Islands. Tectonophysics 691(A, 206-219.

Barrère, D.R., Ebbing, J., Gernigon, L., 2009. Offshore prolongation of Caledonian structures and basement characterization in the western Barents Sea from geophysical modeling. Tectonophysics 470, 71-88.

Barrère, C., Ebbing, J., Gernigon, L., 2011. 3D density and magnetic crustal characterization of the southwestern Barents Shelf: implications for the offshore prolongation of the Norwegian Caledonides. Geoph. J. Int. 184, 1147-1166.

Beranek, L.P., Van Staal, C.R., McClelland, W.C., Israel, S., Mihalynuk, M.G., 2013 Detrital zircon Hf isotopic compositions indicate a northern Caledonian connection for the Alexander terrane. Lithosphere 5 (2), 163-168.
Bergh, S.G., Maher Jr., H.D., Braathen, A., 2011. Late Devonian transpressional tectonics in Spitsbergen, Svalbard, and implications for basement uplift of the SørkappHornsund High. J. Geol. Soc. Lond. 168 (2), 441-456.

Bogdanov, N.A., Khain, V.E., Rozen, O.M., Shipilov, E.V., Vernikovsky, V.A., Drachev, S.S., Kostyuchenko, S.L., Kuzmichev, A.B., Sekretov, S.B., 1998. Tectonic Map of the Kara and Laptev Seas and North Siberia. Russian Academy of Science, Moscow (in Russian).

Breivik, A.J., Mjelde, R., Grogan, P., Shimamura, H., Murai, Y., Nishimura, Y., 2005. Caledonide development offshore-onshore Svalbard based on ocean bottom seismometer, conventional seismic, and potential field data (2005). Tectonophysics 401 (12), 79-117.

Brumley, K., Miller, E.L., Konstantinou, A., Grove, M., Meisling, K.E., Mayer, L.A., 2015 First bedrock samples dredged from submarine outcrops in the Chukchi Borderland, Arctic Ocean. Geosphere 11 (1), 76-92.

Cohen, K.M., Finney, S.C., Gibbard, P.L., Fan, J.-X., 2016. The ICS International Chronostratigraphic Chart. Episodes 36. pp. 199-204. (2013; updated). http://www. stratigraphy.org/ICSchart/ChronostratChart2016-12.pdf.

Colpron, M., Nelson, J.L., 2011. A paleozoic NW passage and the timanian, caledonian and uralian connections of some exotic terranes in the north american cordillera. In: In: Spencer, A.M., Embry, A.F., Gautier, D.L., Stoupakova, A.V., Sorensen, K. (Eds.), Arctic Petroleum Geology, vol. 35. Geological Society London, Memoir, pp. 463-484.

Corfu, F., Andersen, T.B., Gasser, D., 2014. The Scandinavian Caledonides: main features, conceptual advances and critical questions. Geol Soc. Lon. Spec. Pub. 390 (1), 9-43.

Daragan-Suschova, L.A., Petrov, O.V., Daragan-Suschov, Yu, Vasiliev, M.A., 2013. Features of geological structure of the North-Kara shelf on seismic data. Reg. Geol. Metallogeny 54, 5-16 (In Russian).

Drachev, S.S., Malyshev, N.A., Nikishin, A.M., 2010. Tectonic history and petroleum geology of the Russian Arctic Shelves: an overview. In: Vining, B.A., Pickering, S.C. (Eds.), Petroleum Geology: from Mature Basins to New Frontiers. Proceedings of 7th Petroleum Geology Conference. pp. 591-619. http://dx.doi.org/10.1144/0070591.

Eide, E.A., Osmundsen, P.T., Meyer, G.B., Kendrick, M.A., Corfu, F., 2002. The nesna shear zone, north-central Norway: an 40Ar/39Ar record of early Devonian-Early carboniferous ductile extension and unroofing. Norw. J. Geol. 82, 317-339.

Embry, A.F., 1988. Middle-Upper devonian sedimentation in the canadian arctic islands and the ellesmerian orogeny. In: In: MacMillan, N.J., Embry, A.F., Glass, D.J. (Eds.), Devonian of the World, vol. 14. Can. Soc. of Petroleum Geologists, Memoir, pp. $15-28$ (2).

Embry, A.F., 1993. Crockerland - the northern source area for the sverdrup basin, canadian arctic archipelago. In: Vorren, T., Bergsager, E., Dahl-Stamnes, O., Holter, E., Johansen, B., Lie, E., Lund, T. (Eds.), Arctic Geology and Petroleum Potential. Norwegian Petroleum Society Special Publication. 2, pp. 205-216 (Edited by).

Ershova, V.B., Prokopiev, A.V., Khudoley, A.K., Shneider, G.V., Andersen, T., Kallerund, K., Makariev, A.A., Kolchanov, D.A., 2015a. U-Pb dating of detrital zircons from the Lower Paleozoic deposits of the North Kara basin. Doklady Earth Sci. 464 (4), 444-447.

Ershova, V.B., Prokopiev, A.V., Khudoley, A.K., Sobolev, N.N., Petrov, E.O., 2015b. Detrital zircon ages and provenance of the upper paleozoic successions of kotel'ny island (New siberian islands archipelago). Lithosphere 7, 40-45.

Ershova, V.B., Prokopiev, A.V., Khudoley, A.K., Sobolev, N.N., Petrov, E.O., 2015c. U/Pb dating of detrital zircons from Upper Paleozoic deposits of Bel'kovsky Island (New Siberian Islands): critical testing of Arctic tectonic models. Int. Geol. Rev. 57 (2), 199-210.

Ershova, V.B., Prokopiev, A.V., Nikishin, V.A., Khudoley, A.K., Nikishin, A.M., Malyshev, N.A., 2015d. New data on upper carboniferous lower permian deposits of bol'shevik island, Severnaya Zemlya archipelago. Polar Res. http://dx.doi.org/10.3402/polar. v34.24558.

Ershova, V., Prokopiev, A., Khudoley, A., 2016a. Devonian-Permian sedimentary basins and paleogeography of the Eastern Russian Arctic: an overview. Tectonophysics 691 (A, 234-255.

Ershova, V.B., Lorenz, H., Prokopiev, A.V., Sobolev, N.N., Khudoley, A.K., Petrov, E.O., Estrada, S., Sergeev, S., Larionov, A., Thomsen, T.B., 2016b. The De Long Islands: a missing link in unraveling the Paleozoic paleogeography of the Arctic. Gondwana Research. Gondwana Res. 35, 305-322.

Ershova, V., Belyakova, R., Prokopiev, A., Khudoley, A., Faleide, J.I., Gaina, C., Sobolev, N., Petrov, E., 2017a. Basement composition and pre-Mesozoic sedimentary succession of northern barents sea revealed by new data on franz josef land jurassic conglomerates. In: AAPG/SEG International Conference and Exhibition. London, England October 15-18, 2017.

Ershova, V.B., Prokopiev, A.V., Sobolev, N.N., Petrov, E.O., Khudoley, A.K., Faleide, J.I., Gaina, C., 2017b. New data on composition of basement of franz josef land archipelago. Geotectonics 51 (2), 121-130.

Farley, K.A., Wolf, R., Silver, L., 1996. The effects of long alpha-stopping distances on (UTh)/He ages. Geochim. Cosmochim. Acta 60 (21), 4223-4229.

Farley, K.A., 2002. (U-Th)/He dating: techniques, calibrations, and applications. Rev. Mineral. Geochem. 47, 819-844.

Fossen, H., 2010. Extensional tectonics in the North Atlantic Caledonides: a regional view. Geol. Soc. Spec. Publ. 335, 767-793.

Gac, S., Klitzke, P., Minakov, A., Faleide, J.I., Scheck-Wenderoth, M., 2016. Lithospheric strength and elastic thickness of the Barents Sea and Kara Sea region. Tectonophysics 691(A, 120-132.

Gasser, D., Andresen, A., 2013. Caledonian terrane amalgamation of Svalbard: detrital zircon provenance of Mesoproterozoic to Carboniferous strata from Oscar II Land, western Spitsbergen. Geol. Mag. 150 (6), 1103-1126.

Gasser, D., 2014. The Caledonides of Greenland, Svalbard and Other Arctic Areas: Status of Research and Open Questions, vol. 390. Geological Society Special Publication, pp. 93-129 (1). 
Gee, D.G., Bogolepova, O.K., Lorenz, H., 2006. The Timanide, Caledonide and Uralide orogens in the Eurasian high Arctic, and relationships to the palaeocontinents Laurentia, Baltica and Siberia. In: In: Gee, D.G., Stephenson, R.A. (Eds.), European Lithosphere Dynamics, vol. 32. Geological Society London, Memoirs, pp. 507-520.

Gee, D.G., Fossen, H., Henriksen, N., Higgins, A.K., 2008. From the early Paleozoic platforms of Baltica and Laurentia to the Caledonide Orogen of Scandinavia and Greenland. Episodes 31 (1), 44-51.

Gee, D.G., Janák, M., Majka, J., Robinson, P., van Roermund, H., 2013. Subduction along and within the Baltoscandian margin during closing of the lapetus ocean and BalticaLaurentia collision. Lithosphere 5 (2), 169-178.

Gernigon, L., Brönner, M., 2012. Late Palaeozoic architecture and evolution of the southwestern Barents Sea: insights from a new generation of aeromagnetic data. J. Geol. Soc. Lon. 169, 449-459.

Gilotti, J.A., Nutman, A.P., Brueckner, H.K., 2004. Devonian to Carboniferous collision in the Greenland Caledonides: U-Pb zircon and Sm-Nd ages of high-pressure and ultrahigh-pressure metamorphism. Contrib. Miner. Petrol 148 (2), 216-235.

Gilotti, J.A., McClelland, W.C., Wooden, J.L., 2014. Zircon captures exhumation of an ultrahigh-pressure terrane. North-East Greenland Caledonides: Gondwana Res. 25 (1), 235-256.

Gramberg, I.S., Ushakov, V.I., 2000. Severnaya Zemlya - Geology and Mineral Resources. VNIIOkeangeologia, St. Petersburg (in Russian).

Gudlaugsson, S.T., Faleide, J.I., Johansen, S.E., Breivik, A.J., 1998. Late Paleozoic structural development of the south-western Barents Sea. Mar. Petrol.Geol. 15, 73-102.

Hadlari, T., Davis, W.J., Dewing, K., 2014. A Pericratonic Model for the Pearya Terrane as an Extension of the Franklinian Margin of Laurentia, vol. 126. Bull. of the Geol. Soc of Amer., Canadian Arctic, pp. 182-200 (1-2)

Harrison, J.C., Brent, T.A., 2005. Basins and fold belts of Prince Patrick Island and adjacent areas, Canadian Arctic Islands. Geol. Surv. Can. Bull. 560, 197.

Harrison, J.C., 1995. Melville Island's Salt-based Fold Belt. Geological Survey of Canada, Arctic Canada, pp. 344.

Henriksen, E., Ryseth, A.E., Larssen, G.B., Heide, T., Ronning, K., Sollid, K., Stoupakova, A.V., 2011. Tectonostratigraphy of the Greater Barents Sea: Implications for Petroleum Systems, vol. 35. Geol. Soc., London, Memoirs, pp. 163-195.

Higgins, A.K., Soper, N.J., Leslie, A.G., 2000. The ellesmerian and caledonian orogenie belts of Greenland. Polarforschung 68, 141-151.

Klitzke, P., Faleide, J.I., Scheck-Wenderoth, M., Sippel, J., 2015. A lithosphere-scale structural model of the Barents Sea and Kara Sea region. Solid Earth 6, 153-172.

Knudsen, C., Hopper, J.R., Bierman, P.R., Bjerager, M., Funck, T., Green, P.F., Ineson, J.R., Japsen, P., Marcussen, C., Sherlock, S.C., Thomsen, T.B., 2018. Samples from the Lomonosov Ridge place new constraints on the geological evolution of the Arctic Ocean. In: In: Pease, V., Coakley, B. (Eds.), Circum-Arctic Lithosphere Evolution., vol. 460. Geological Society London, Special Publications, pp. 397-418.

Kosmínska, K., Majka, J., Manecki, M., Schneider, D., 2016. First evidence of the Ellesmerian metamorphism on Svalbard. Geoph. Res. Abst. 18, EGU2016-1219.

Lane, L.S., 2007. Devonian-Carboniferous paleogeography and orogenesis, northern Yukon and adjacent Arctic Alaska. Can. J. Earth Sci. 44, 679-694.

Lane, L.S., Gehrels, G.E., Layer, P.W., 2016. Provenance and paleogeography of the neruokpuk formation, northwest Laurentia: an integrated synthesis. Bull. Geol. Soc. Am. 128 (1-2), 239-257.

Lawver, L.A., Grantz, A., Gahagan, L.M., 2002. Plate kinematic evolution of the present Arctic region since the Ordovician. In: Miller, E.L., Grantz, A., Klemperer, S.L. (Eds.), Tectonic Evolution of the Bering Shelf-Chukchi Sea-Arctic Margin and Adjacent Landmasses. Special Paper. Geol. Soc. of America, Boulder, CO, pp. 333-358.

Lorenz, H., Gee, D.G., Whitehous, M., 2007. New geochronological data on Palaeozoic igneous activity and deformation in the Severnaya Zemlya Archipelago Russia, and implications for the development of the Eurasian Arctic margin. Geol. Mag. 144, $105-125$.

Lorenz, H., Mannik, P., Gee, D., Proskurnin, V., 2008a. Geology of the Severnaya Zemlya Archipelago and the North Kara Terrane in the Russian high Arctic. Inter. J. Earth Sci. 97, 519-547.

Lorenz, H., Gee, D.G., Simonetti, A., 2008b. Detrital zircon ages and provenance of the Late Neoproterozoic and Palaeozoic successions on Severnaya Zemlya, Kara Shelf: a tie to Baltica. Norw. J. Geol. 88 (4), 235-258.

Lorenz, H., Gee, D.G., Larionov, A.N., Majka, J., 2012. The Grenville-Sveconorwegian orogen in the high. Arctic. Geol. Mag. 149 (5), 875-891.

Lorenz, H., Gee, D.G., Korago, E., Kovaleva, G., Mcclelland, W.C., Gilotti, J.A., Frei, D. 2013. Detrital zircon geochronology of Palaeozoic Novaya Zemlya - a key to understanding the basement of the Barents Shelf. Terra Nova 25 (6), 496-503.

State geological map of the Russian Federation. In: Makariev, A.A. (Ed.), State Geological Map of the Russian Federation. VSEGEI publishing, St. Petersburg Scale 1:1 000000 (third generation). Sheet T-45 - 48th. Cheliuskin.

Marcussen, C., Knudsen, C., Funck, J., Ineson, J.R., Bjerager, M., 2015. Age and origin of the Lomonosov Ridge: a key continental fragment in Arctic Ocean reconstructions. Geoph. Res. Abst. 17 (EGU General Assembly EGU2015-10207-1).

Markovsky, V.A., Paderin, P.G., Shneider, G.B., Lazareva, L.N., Kuz'min, V.G., Lazurenko VI., , 1988. State Geological Map of the Russian Federation. VSEGEI Publishing House, St. Petersburg Scale 1:200 000. Sheet T-47-VI, XI, XII; T-48-I, VII, VIII, IX, X;
T-47-XVI, XVII, XVIII, XXII, XXIII; T-48-XIII, XIV, XV, XVI, XVII, XVIII (Bol'shevik Island).

Matukhin, R.G., Menner, V.V. (Eds.), 1999. Stratigraphy Silurian and Devonian Strata of Severnaya Zemlya. SNIIGIMS Publishing House, Novosibirsk, pp. 174 (in Russian).

McKerrow, W.S., Mac Niocaill, C., Dewey, J.F., 2000. The caledonian orogeny redefined. J. Geol. Soc. 157 (6), 1149-1154.

Metelkin, D.V., Kazansky, Yu.A., Vernikovsky, V.A., Gee, D.G., Torsvik, T., 2000. First palaeomagnetic data on the early Palaeozoic rocks from Severnaya Zemlya (Siberian Arctic) and their geodynamic interpretation. Geol. Geoph. 41, 1816-1820 (in Russian).

Miller, E.L., Gehrels, G.E., Pease, V., Sokolov, S., 2010. Stratigraphy and U-Pb detrital zircon geochronology of wrangel island, Russia: implications for arctic paleogeography. Am. Assoc. Petrol Geol. Bull. 94, 665-692.

Miller, E.L., Kuznetsov, N., Soboleva, A., Udoratina, O., Grove, M.J., Gehrels, G., 2011. Baltica in the cordillera? Geology 39, 791-794.

Morozov, A.F., Petrov, O.V., 2004. State Geological Map of the Russian Federation. Scale 1:2500 000. VSEGEI Publishing House, St. Petersburg (in Russian).

O'Brien, T.M., Miller, E.L., Benowitz, J.P., Meisling, K.E., Dumitru, T.A., 2016. Dredge samples from the Chukchi Borderland: implications for paleogeographic reconstruction and tectonic evolution of the Amerasia Basin of the Arctic. Am. J. Sci. 316 (9), 873-924.

Pease, V., Scott, R.A., 2009. Crustal affinities in the Arctic Uralides, northern Russia: significance of detrital zircon ages from Neoproterozoic and Palaeozoic sediments in Novaya Zemlya and Taimyr. J. Geol. Soc. 166 (3), 517-527.

Pease, V., Gee, D., Lopatin, B., 2001. Is Franz Josef Land Affected by Caledonian Deformation?. Symposium RCM7. Tectonics and Sedimentation Associated with Arctic Margins.

Piepjohn, K., von Gosen, W., Tessensohn, F., Saalmann, K., 2008. Ellesmerian fold-andthrust belt (northeast ellesmere island, nunavut) and its Eurekan overprint. Geol. Survey Can. Bull. 592, 285-303.

Piepjohn, K., von Gosen, W., Tessensohn, F., Reinhardt, L., McClelland, W.C., Dallmann, W., Gaedicke, C., Harrison, J.C., 2015. Tectonic map of the Ellesmerian and Eurekan deformation belts on Svalbard, North Greenland, and the Queen Elizabeth Islands (Canadian Arctic) Arktos. http://dx.doi.org/10.1007/s41063-015-0015-7.

Piepjohn, K., 2000. The svalbardian-Ellesmerian deformation of the old red sandstone and the pore-Devonian basement in NW spitsbergen (Svalbard). In: Friend, P.F., Williams, B.P.J. (Eds.), New Perspectives on the Old Red Sandstone. Geological Society, London, pp. 585-601 (Special Publications. 180).

Prokopiev, A., Ershova, V., Anfinson, O., Khudoley, A., Vasiliev, D., Stockli, D., 2015. Tectonics of New Siberia Islands: structural styles and zircon U-Th/He ages. In: Smelror, M. (Ed.), Abstracts of 7th International Conference on Arctic Margins (ICAMVII). Trondheim, Norway, Geological Survey of Norway, Report No.: 2015.032, pp. 120-121.

Reiners, P.W., Spell, T.L., Nicolescu, S., Zanetti, K.A., 2004. Zircon (U-Th)/He thermochronometry: He diffusion and comparisons with 40Ar/39Ar dating. Geoch. et Cosmochi Acta 68 (8), 1857-1887.

Reiners, P.W., 2005. Zircon (U-Th)/He thermochronometry. In: In: Reiners, R.W., Ehlers, T.A. (Eds.), Low-Temperature Thermochronology: Techniques, Interpretations, and Applications, vol. 58. pp. 151-179 Rev. Mineral. Geochem.

Rippington, S., Scott, R.A., Smyth, H., Bogolepova, O., Gubanov, A., 2010. The ellesmerian orogeny: fact or fiction? GeoCanada - 1-4 (2010).

Ritzmann, O., Faleide, J.I., 2009. The crust and mantle lithosphere in the Barents Sea/ Kara Sea region. Tectonophysics 470, 89-104.

Roberts, D., 2003. The Scandinavian Caledonides: event chronology, palaeogeographic settings and likely modern analogues. Tectonophysics 365 (1-4), 283-299.

Soper, N.J., Higgins, A.K., 1990. Models for the Ellesmerian mountain front in North Greenland: a basin margin inverted by basement uplift. J. Struct. Geol. 12 (1), 83-97.

Spikings, R., Simpson, G., 2014. Rock uplift and exhumation of continental margins by the collision, accretion, and subduction of buoyant and topographically prominent oceanic crust. Tectonics 33 (5), 635-655.

Sturt, B.A., Braathen, A., 2001. Deformation and metamorphism of Devonian rocks in the outer Solund area, western Norway: implication for models of Devonian deformation. Inter. J. Earth Sci. 90 (2), 270-286.

Torsvik, T.H., Sturt, B.A., Ramsay, D.M., Kisch, H.J., Bering, D., 1986. The tectonic implications of Solundian (Upper Devonian) magnetization of the Devonian rocks of Kvamshesten, western Norway. Earth Planetary Sci. Lett. 80, 337-347.

Trettin, H.P., 1987. Pearya: a composite terrane with Caledonian affinities in northern Ellesmere Island. Can. J. Earth Sci. 24 (2), 224-245.

Vernikovsky, V.A., 1996. Geodynamic Evolution of the Taimyr Folded Region. Publishing House of the Siberian Division of RAS, Novosibirsk (in Russian).

Verzhbitsky, V.E., Sokolov, S.D., Tuchkova, M.I., 2015. Present-day structure and stages of tectonic evolution of Wrangel Island, Russian eastern Arctic Region. Geotectonics 49 (3), 165-192.

Wolfe, M.R., Stockli, D.F., 2010. Zircon (U-Th)/He thermochronometry in the KTB drill hole, Germany, and its implications for bulk He diffusion kinetics in zircon. Earth Planet. Sci. Lett. 295 (1-2), 69-82.

Zonenshain, L.P., Kuz'min, M.I., Natapov, L.M., 1990. Geology of the USSR: a Plate-tectonic Synthesis. Geodynamics Series 21. American Geophysical Union, Washington. 